\title{
OCCURRENCE, DENSITY AND INJURY OF CERTAIN INSECTS INFESTING BRUSSELS SPROUTS AND ONION CROPS IN THE DESERT LANDS AT EL- NOUBARREIA, BEHERA GOVERNORATE
}

\author{
(Received: 4.8.2009)
}

\author{
By \\ H.A. Salem and Sh. E. Abd El-Aziz \\ Department of Pests \& Plant Protection, National Research Center, Dokki, Giza, Egypt.
}

\begin{abstract}
This work was conducted at the Experimental and Production Farm of the National Research Center at El-Noubarreia, Behera Governorate during two seasons 2005/2006 and 2006/2007, in response to lack of information about insect species infesting Brussels sprouts and onion crops in the newly desert land, population density and final injury caused by certain insect species. Results indicated that Brussels sprouts are infested by Brevicoryne brassicae L., Bemisia tabaci (Genn.) and Plutelta xylostella L. Thrips tabaci (L.) is the main insect pest on onion plants.

Winged adults of $B$. brassicae on Brussels sprouts plants had two and three peaks of activity during the seasons of 2005/2006 and 2006/2007, respectively. Also winged adults caught by sticky traps had 2-3 peaks of activity. Wingless individuals of aphid (adults + nymphs) passed by 3 peaks during experimental period. The highest increase quotients in the population density of aphids in the $1^{\text {st }}$ season were 2.38 and 2.54 on January 5 and March 16, respectively; in the $2^{\text {nd }}$ season the highest increase quotients were 13.78 and 7.93 on November, 28 and January 23, respectively. Parasitism by Diaeretiella rapae on B. brassicae reached its highest at $30.6 \%$.

Whitefly adults showed two peaks of activity on Brussels sprouts in the first season. Nymphs had one peak of activity, with highest counts (112.8 nymphs/ leaf) at temperature $15.7^{\circ} \mathrm{C}$ and relative humidity $70.32 \%$, but it had low numbers in the $2^{\text {nd }}$ season.

T. tabaci had 1-2 peaks / season, with the highest counts ( 88.8 and 72.13 individuals/ plant) at temperature $19.8 \& 18.37^{\circ} \mathrm{C}$ and relative humidity $61.3 \& 59.7 \%$ in 2006 and 2007, respectively.

The final injury by B. brassicae on Brussels sprouts heads represented in $60.0,40.0 \& 0.0 \%$ and $13.3,20.0 \& 66.7 \%$ of heads had severe, medium and light infestation in the lower and upper half level of the stem, respectively. Also $53.3 \& 46.7 \%$ and $43.3 \& 56.7 \%$ of the heads suffered from partial eating and holes in their leaves by $P$. xylostella larvae in the lower and upper half levels of the stem, respectively.
\end{abstract}

Key words: Bemisia tabaci, Brevicoryne brassicae, Brussels sprouts, Diaeretiella rapae, final injury, onion, peak of activity, Plutella xylostella, Thrips tabaci.

\section{INTRODUCTION}

Brussels sprouts (Brassica oleraceae L. gemmifera) is a new cruciferous crop in Egypt; also the onion Allium cepa $\mathrm{L}$. plays an important role in agricultural income. These crops are important in feeding, processing and exporting. These crops are infested and injured by many insect pests. Salem (2002) showed that cabbage seedlings are infested with insect species Brevicoryne brassicae L., Thrips tabaci (Lind.), Bemisia tabaci (Genn.), Liriomyza brassicae, Artogeia rapae (L.) and Phyllotreta crucifera (Goezel) in Giza Governorate. BadensPerez and Shelton (2006) in Kenya and India mentioned that cruciferous vegetables are infested by the diamondback moth Plutella xylostella, Agrotis ipsilon, Pieris brassicae, cabbage aphid
Brevicoryne brassicae, Lipaphis erysimi, Myzus persicae, Heliothis armigera and Delia radicum. $B$. brassicae and M. persicae were the most widespread aphids on cruciferous crops in Iran (Farzadfar et al., 2007). T. tabaci is the main insect on onion in New Zealand (Martin et al., 2006).

El-Gindy (1997) and Salem (2003) found that $B$. brassicae had two peaks of activity on cabbage plants during the winter season. Perry et al.(1998) estimated the population of B. brassicae (L.) on Brussels sprouts plants on the basis of biweekly samples during 1996 in 2 ha blocks. Yield losses caused by B. brassicae on canola plants can exceed 50\% in Poland, India, China, Australia and New Zealand (Bakhetia, 1983; Kelm and Godomski, 1995). Diaeretiella rapae (M'Intosh) parasitized on $B$. brassicae in cabbage and turnip 
crops at higest percents (40.20\% and 32.64\%), respectively (Bayhan et al., 2007). Farag (1995) found that the highest percentage of aphid population at Giza and Qualubia was 27\%, and it was 32\% at Sharkia Governorates.

Hegab and Helaly (1989) recorded two peaks of $B$. tabaci adults on cabbage and cauliflower plants at Sharkia Governorate. Yellow sticky traps were used for monitoring adult populations of $B$. tabaci (Ohnesorge and Rapp, 1986).

Population density of T. tabaci on onion plants reached its highest at 130 and 158 days after planting (Kalafchi et al., 2006). The highest abundance of $T$. tabaci on leek plants was in late July 2004 and early August 2005 (Douchovskiene, 2006).

In accordance with the increase of demands, the main aim of this work was to determine the following: insect species that may infest Brussels sprouts and onion crops, their density in the desert, the potential injury caused by these insects, and the value of this injury.

\section{MATERIALS AND METHODS}

\subsection{Culture}

This work was conducted during two seasons (2005/2006 and 2006/2007) in the Experimental and Production Farm of the National Research Center at El-Noubarreia district, Behera Governorate, along the Alexandria desert road, about $170 \mathrm{~km}$ from Cairo. Seedlings of Brussels sprouts cv. Jud Cross and onion cv. Giza 20 (7 weeks old) were transplanted on 15 October 2005 and 12 October 2006 for Brussels sprouts and on 15 January 2006 and 28 December 2006 for onion plants in the two successive seasons. Seedlings were transplanted in rows, each $40 \mathrm{~m}$. long; drip irrigation was used. The experimental area of each crop was divided into three plots used as replicates. Plots were kept free of pesticides. Number of rows / plot differed by crop and seasons: at least 8 rows in Brussels sprouts, 14 for onion. The distance between rows was $1 \mathrm{~m}$. The total experimental area of Brussels sprouts was at least $450 \mathrm{~m}^{2}$; and it was about $700 \mathrm{~m}^{2}$ for onion.

\subsection{Insect monitoring}

Random methods were followed by examining 15 leaves (5 leaves / plot) directly on plants by hand lens to count the winged adults of cabbage aphid and whitefly; the same leaves were picked gently, put in polyethylene plastic bags and transferred to be examined in the laboratory by binocular microscope to count whitefly nymphs, wingless individuals of aphids (adults and nymphs), and aphids (mummies) parasitized by Diaeretiella rapae (M' Intosh). Also the numbers of diamondback moth larvae were considered.
Samples were taken biweekly according to Perry et al., 1998). The same method was follwed to sample thrip counts on 15 onion plants (5 plants / plot), examined directly in the field. Four yellow sticky traps were used for monitoring whitefly adults and winged adults of aphids on Brussels sprouts according to Hirano et al. (1993) and Ohnesorge and Rapp (1986). These traps were replaced biweekly by new ones; and the insects caught on sticky cards were defined and counted by binocular microscope.

\subsection{Analysis and calculations}

Readings of temperature and relative humidity were obtained from the Central Laboratory for Agriculture Climate (Agricultural Research Center, Giza). Simple correlation coefficient and regression were calculated between the total counts of insects and means of climatic factors (Gomez and Gomez, 1984). Also the quotient of increase in aphid population was calculated according to Bodenheimer (1951).

\section{The quotient of increase $=$}

$$
\begin{aligned}
& \text { Population of one month } \\
& \hline \text { Population of preceding month }
\end{aligned}
$$

The percentage of parasitism by $D$. rapae on aphid population was calculated as

\section{Percentage of parasitism=}

$$
\frac{\text { Number of mummies }}{\text { Total population of aphids }} \text { X100 }
$$

\subsection{Injury assessment}

To assess the final injury caused by cabbage aphid and diamondback moth larvae on the heads and leaves of Brussels sprouts during the 2006/2007 season at harvest, fifteen heads were picked up randomly from the lower half of stems and another 15 heads from the upper half. Each of them was sacked and transferred to the laboratory to dissect. Parameters referring to injury were recorded. Parameters of aphid injury were: aphid counts / head, number of heads with honeydew \& exuviae; on the basis of these parameters four degrees of infestation were established. Severely infested heads $(60-100 \%$ of head leaves were injured), medium infested heads ( 25 $\leq 60 \%$ of head leaves were injured), light infested heads $(<25 \%$ infested leaves), and healthy heads. Parameters of diamondback moth injury were: larval counts / head, heads with faeces, heads with partial eating, heads with holes in their leaves, and healthy heads. Counts of heads in every parameter were converted into percentage. The final injury on Brussels sprouts leaves was assessed by the same 
manner on 30 leaves, which were picked randomly at harvest time.

\section{RESULTS AND DISCUSSION \\ 3.1. Occurrence and density of Brussels sprouts insects}

Cabbage aphid: The winged adults of Brevicoryne brassicae L. had two peaks of abundance, lasting from October, 27 to February, 2 and from February, 2 to March, 16 (Fig.1), with the highest rates of 1.33 and 15.53 individuals/ leaf at the end of November and end of the 2005/ 2006 season when temperatures were 23.85 and $17.95 \circ \mathrm{C}$ and relative humidity 64.35 and $62.5 \%$, respectively (Table 1 ). Two peaks were obtained by yellow sticky traps, with the highest counts (14.25 and 12.7 adults / trap) at the same dates mentioned previously. In the $2^{\text {nd }}$ season, the highest number of winged adults (Fig. 1) was 5.07 individuals / leaf at the mid of the season. The highest number of adults caught by sticky traps was 32.7 / trap, at the end of January.

Activity of wingless individuals of cabbage aphid was represented in three periods during the winter of 2005/2006 (October, 27- December, 8), (December, 8 - February, 2) and (February, 2 - March, 16); and three periods during 2006/2007 (October, 31 December, 26), (December, 26 - February, 6) and (February, 6 - March, 20) (Fig .1). The highest numbers recorded in the $1^{\text {st }}$ and $2^{\text {nd }}$ seasons were 151.4 and 180.6 individuals / leaf, respectively.

The virtual increase in the population density of aphid could be deduced by calculating the quotient of increase (Table 1); its value during the $1^{\text {st }}$ season reached the maximum (2.38 and 2.54) on January 5 and March 16 when temperatures were $15.7 \& 17.95^{\circ} \mathrm{C}$, and relative humidity was $70.32 \& 62.5 \%$ respectively. Values of these parameters in the $2^{\text {nd }}$ season were the highest at 13.78 and 7.93 on November, 28 and January, 23 when temperature was 14.3 and $14.12^{\circ} \mathrm{C}$ and relative humidity 65.8 and $67.75 \%$, respectively. These results corresponded with the results of ElGindy (1997) and Salem (2003) who found that $B$. brassicae had two peaks of abundance on cabbage plants during winter seasons.

Percentage of the aphids (mummies) parasitized by the aphid parasite Diaeretiella rapae (M, Intosh) was low at the beginning of both seasons and accumulated gradually to become 30.6 and $12.35 \%$ near the end of 2005 / 2006 and 2006/2007, respectively. This agrees with the results of Farag (1995) who mentioned that this percentage was 27\%, and Bayhan et al. (2007) who found that the highest percentage of parasitism by $D$. rapae on $B$. brassicae was $40.2 \%$.

Cotton whitefly: Data in Table (1) show that B. tabaci adults had two peaks of activity during the $1^{\text {st }}$ season. The first peak occurred directly after transplantation with a rate of 18 adults / leaf. The $2^{\text {nd }}$ one occurred almost at the last half of the season with rate of 11.8 adults / leaf. The same trend was obtained by using sticky traps, where the highest counts were 21 and 13 adults / trap. Nymphs had one peak of activity during the same season and reached its highest 112.8 nymphs / leaf at the beginning of January $\left(15.7^{\circ} \mathrm{C}, 870.32 \%\right.$ R.H.). However in the $2^{\text {nd }}$ season, both adults and nymphs had low numbers (Table 1). This may be attributed to the relatively colder weather in the $2^{\text {nd }}$ season than in the $1^{\text {st }}$ one, and to crop structure differences. In the $1^{\text {st }}$ season potato and beet plantation was dominant in the region, whereas wheat was the dominant crop in the $2^{\text {nd }}$ season.

This agrees with the results obtained by Hegab and Helaly (1989) who reported two peaks of B. tabaci adults on cabbage and cauliflower plants in Sharkia Governorate. Larvae of $P$. xylostella were noticed with little numbers on Brussels sprouts leaves in both seasons (Table 1).

\subsection{Occurrence and density of onion thrips}

Data in Table (2) show that Thrips tabaci attacked onion plants in the first season with the highest numbers (88.8 individuals / plant) on April 18,2006 at a temperature $19.8{ }^{\circ} \mathrm{C}$ and relative humidity $61.3 \%$. In the $2^{\text {nd }}$ season, thrips had two periods of activity that lasted from January 9 to March 20 and from March 20 to May 15. The second period had the highest peak $(72.13$ individuals / plant) at a temperature of $18.37{ }^{\circ} \mathrm{C}$ and relative humidity $59.7 \%$. This result corresponds with the findings of Kalafachi et al. (2006) who reported that the population density of thrips had two peaks of activity on onion plants.

\subsection{Effect of temperature and relative humidity on the investigated insects}

As shown in Table (3), the calculated values indicate that an insignificant correlation was obtained between climatic factors and either cabbage aphid, whitefly or thrips. This agreed with results of Salem (2003) who found that temperdture and relative humidity had insignificant effects on nymphs and adults of $B$. brassicae infesting cabbage plantations. The same climatic factors had insignificant effects on $T$. tabaci infesting cabbage and faba bean (Salem et al., 2004). Hirano et al. (1993 \& 1995) mentioned that climatic factors did not play a major role in population fluctuations of B. tabaci. 

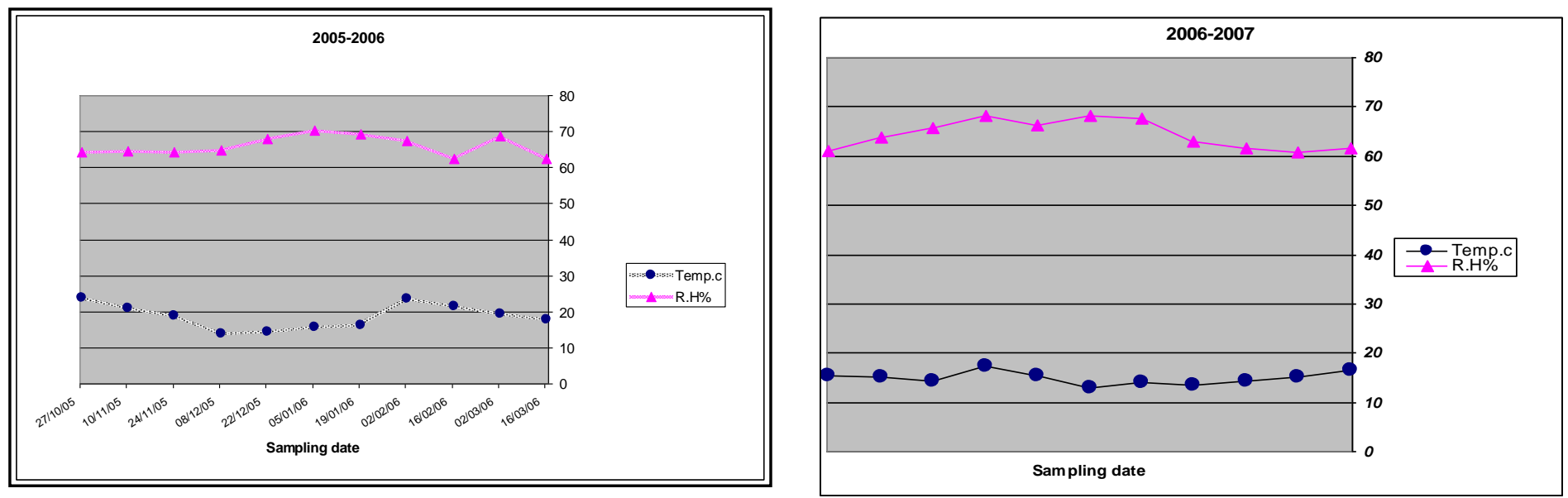

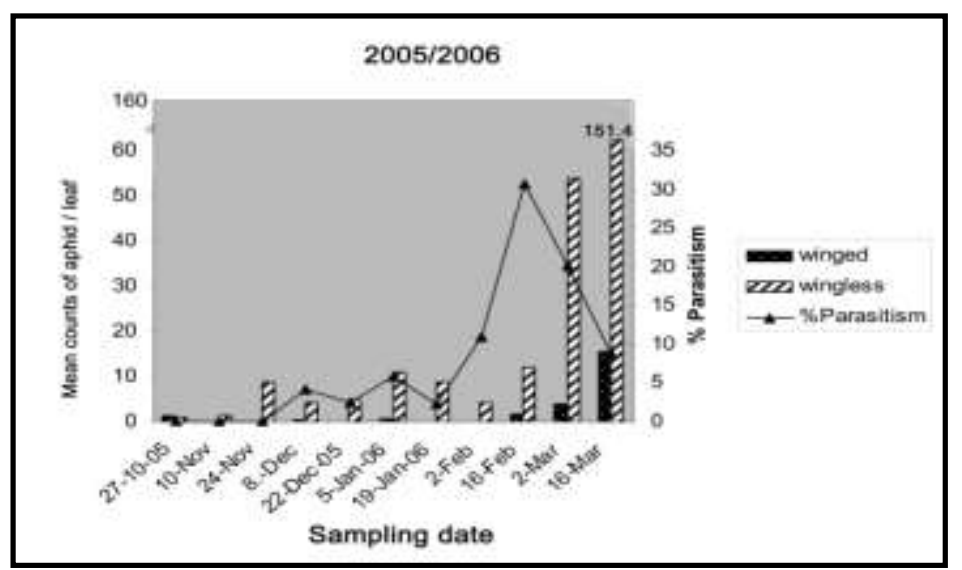

(a)

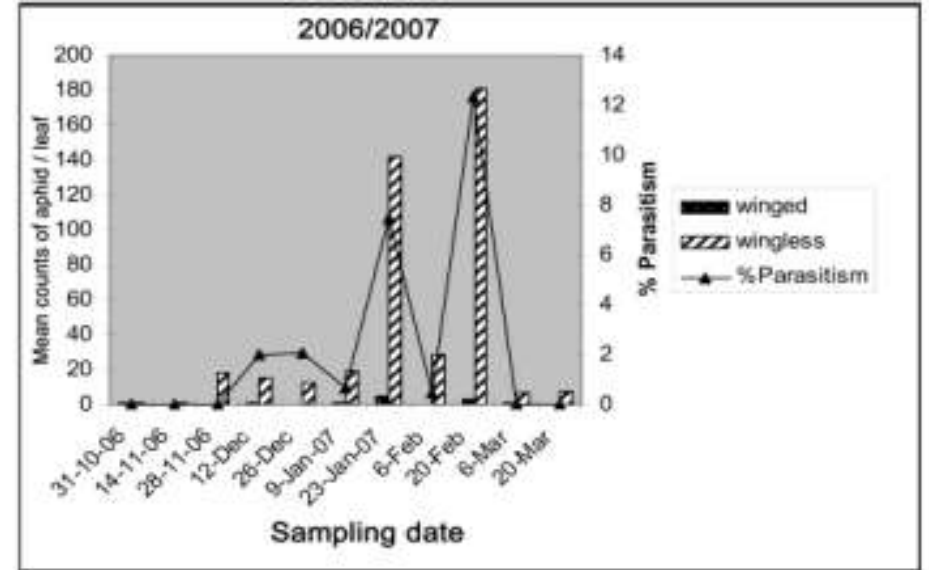

(b)

Fig (1): Mean counts of winged \&wingless individuals of Brevicoryne brassicae L. on Brussels sprouts and percentage of parasitism by Diaeretiella rapae (M. Intosh) during the winter seasons of 2005/2006 (a) and 2006/2007(b) at El-Noubarreia, Behera Governorate. 
Table (1): Counts of cabbage aphid (Brevicoryne brassicae L.), cotton whitefly (Bemisia tabaci (Genn.) and diamondback moth (Plutella xylostella L.) per leaf of Brussels sprouts corresponding to biweekly average temp. $\left({ }^{\circ} \mathrm{C}\right) ; \&$ R.H. $(\%)$ during the two seasons at El-Noubarreia, Behera Governorate.

\begin{tabular}{|c|c|c|c|c|c|c|c|c|c|c|}
\hline \multirow{3}{*}{ Season } & \multirow{3}{*}{ Sampling date } & \multicolumn{3}{|c|}{ Aphid counts } & \multicolumn{3}{|c|}{ Whitefly counts } & \multirow{3}{*}{$\begin{array}{c}\text { Diamondback } \\
\text { moth larvae } \\
\text { counts/leaf }\end{array}$} & \multicolumn{2}{|c|}{ Climatic factors } \\
\hline & & \multirow{2}{*}{$\begin{array}{c}\text { Winged } \\
\text { adults/ } \\
\text { trap }\end{array}$} & \multirow{2}{*}{$\begin{array}{c}\text { Total } \\
\text { population / } \\
\text { leaf }\end{array}$} & \multirow{2}{*}{$\begin{array}{l}\text { Quotient } \\
\text { of increase }\end{array}$} & \multicolumn{2}{|c|}{ Adults } & \multirow{2}{*}{ Nymphs } & & \multirow{2}{*}{ Temp. ${ }^{\circ} \mathrm{C}$} & \multirow{2}{*}{ R.H\% } \\
\hline & & & & & /leaf & $/$ trap & & & & \\
\hline $2005 / 2006$ & $\begin{array}{lr}\text { October } & 27 \\
\text { November } 10 \\
24 \\
\text { December } 8 \\
& 22 \\
\text { January } & 5 \\
& 19 \\
\text { February } & 2 \\
& 16 \\
\text { March } & 2 \\
& 16\end{array}$ & $\begin{array}{c}- \\
12.75 \\
14.25 \\
9.25 \\
2.0 \\
4.25 \\
2.0 \\
0.0 \\
0.0 \\
10.75 \\
12.75\end{array}$ & $\begin{array}{c}2.33 \\
1.33 \\
8.8 \\
4.94 \\
5.2 \\
12.39 \\
8.87 \\
4.86 \\
19.6 \\
72.2 \\
183.2\end{array}$ & $\begin{array}{l}\overline{0.57} \\
6.62 \\
0.56 \\
1.05 \\
2.38 \\
0.72 \\
0.55 \\
4.03 \\
3.68 \\
2.54\end{array}$ & $\begin{array}{c}18.0 \\
13.0 \\
7.4 \\
5.4 \\
3.8 \\
4.8 \\
2.87 \\
11.8 \\
6.2 \\
0.2 \\
0.2\end{array}$ & $\begin{array}{c}- \\
21.0 \\
18.25 \\
7.5 \\
5.0 \\
8.0 \\
10.75 \\
13.0 \\
3.0 \\
2.0 \\
1.5\end{array}$ & $\begin{array}{c}2.0 \\
8.33 \\
15.35 \\
23.53 \\
89.87 \\
112.8 \\
16.0 \\
0.33 \\
2.0 \\
2.5 \\
3.33\end{array}$ & $\begin{array}{c}0.2 \\
0.0 \\
0.13 \\
0.0 \\
0.07 \\
0.0 \\
0.0 \\
0.0 \\
0.0 \\
0.0 \\
0.2\end{array}$ & $\begin{array}{c}23.85 \\
20.96 \\
18.82 \\
13.95 \\
14.47 \\
15.7 \\
16.2 \\
23.5 \\
21.5 \\
19.3 \\
17.95\end{array}$ & $\begin{array}{c}64.35 \\
64.5 \\
64.18 \\
64.8 \\
67.9 \\
70.32 \\
69.3 \\
67.4 \\
62.3 \\
68.6 \\
62.5\end{array}$ \\
\hline $2006 / 2007$ & 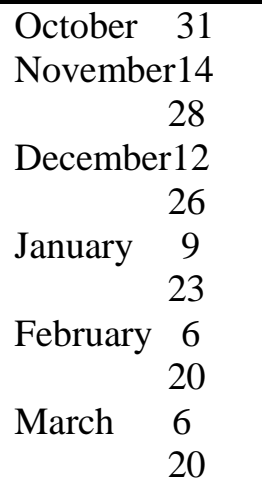 & $\begin{array}{c}\overline{10.25} \\
17.25 \\
15.25 \\
4.25 \\
6.25 \\
32.75 \\
25.75 \\
14.75 \\
7.0 \\
9.0\end{array}$ & $\begin{array}{c}2.0 \\
1.33 \\
18.33 \\
16.26 \\
13.13 \\
20.0 \\
158.67 \\
28.93 \\
208.93 \\
6.86 \\
7.47\end{array}$ & $\begin{array}{c}- \\
0.67 \\
13.78 \\
0.89 \\
0.81 \\
1.52 \\
7.93 \\
0.2 \\
7.22 \\
0.03 \\
1.09\end{array}$ & $\begin{array}{c}5.0 \\
3.0 \\
1.27 \\
1.33 \\
0.53 \\
0.2 \\
0.13 \\
0.0 \\
0.0 \\
0.0 \\
0.0\end{array}$ & $\begin{array}{l}- \\
3.5 \\
2.0 \\
2.0 \\
0.5 \\
1.0 \\
0.0 \\
0.0 \\
0.0 \\
0.0 \\
0.0\end{array}$ & $\begin{array}{c}1.0 \\
0.0 \\
0.0 \\
1.87 \\
2.46 \\
0.33 \\
0.33 \\
0.07 \\
0.0 \\
0.0 \\
0.0\end{array}$ & $\begin{array}{c}0.2 \\
0.0 \\
0.2 \\
0.07 \\
0.0 \\
0.07 \\
0.13 \\
0.2 \\
0.2 \\
0.4 \\
0.07\end{array}$ & $\begin{array}{c}15.5 \\
15.12 \\
14.3 \\
17.4 \\
15.3 \\
12.8 \\
14.12 \\
13.6 \\
14.2 \\
15.2 \\
16.46\end{array}$ & $\begin{array}{c}61.1 \\
63.8 \\
65.8 \\
68.2 \\
66.2 \\
68.14 \\
67.57 \\
62.9 \\
61.6 \\
60.7 \\
61.71\end{array}$ \\
\hline
\end{tabular}


Table (2): Mean counts of onion thrips (Thrips tabaci (Lind.)) on onion plants corresponding to biweekly average of temp. $\left({ }^{\circ} \mathrm{C}\right) \stackrel{\circ}{\&}$ R.H. (\%) during the two seasons at El-Noubarreia, Behera Governorate.

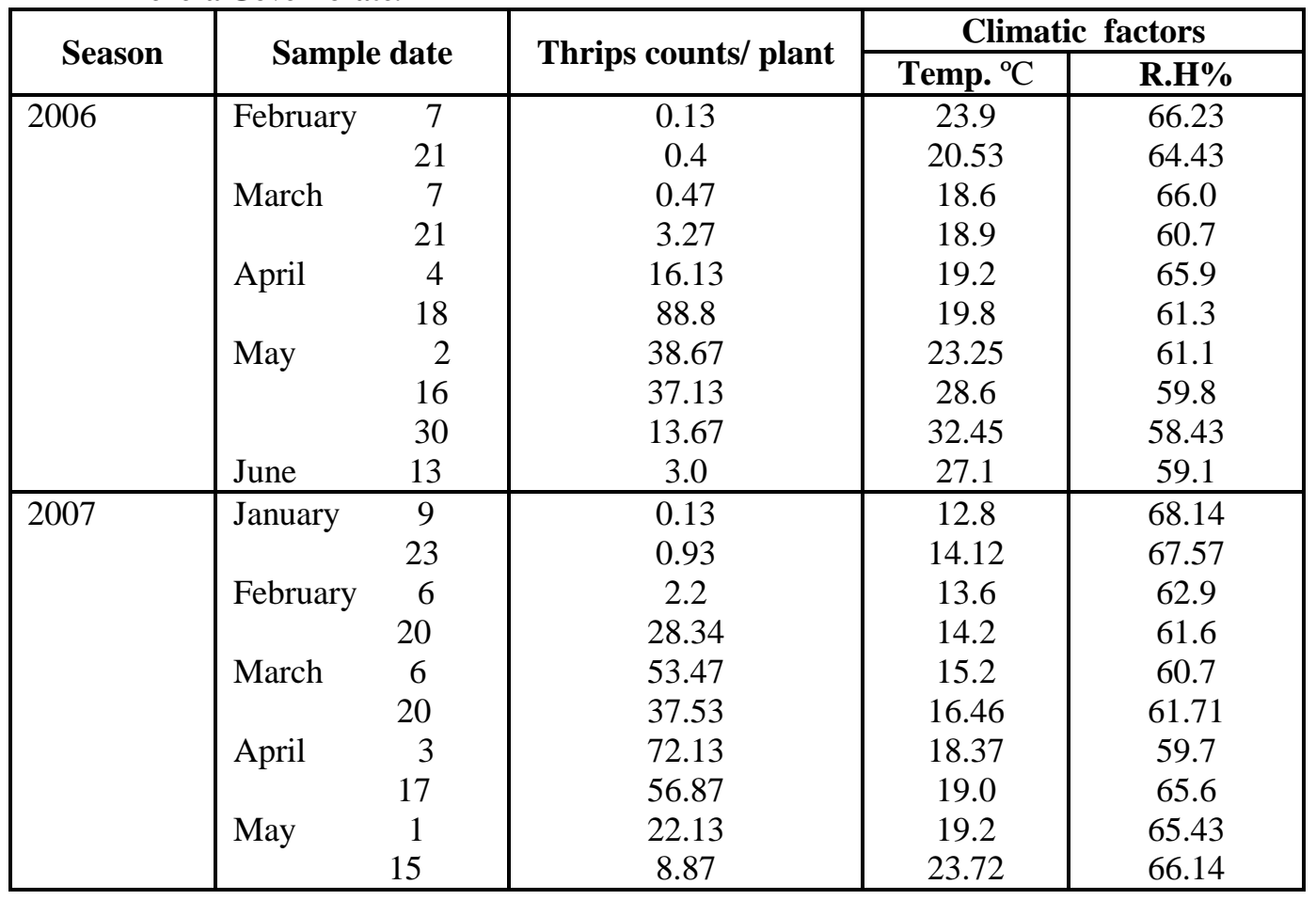

\subsection{The potential injury on Brussels sprouts heads}

Data in Table (4) show that heads present on the lower half of the plant stem harboured higher counts of aphid (36.1 individuals / head) than heads of the upper half which harboured 9.9 individuals / head. A percentage of $93.3 \%$ of the lower heads was contaminated with honeydew and exuviae, $60.0 \%$ of the lower heads were severly infested, $40.0 \%$ of them had medium infestation and no heads had light infestation or were healthy, in comparison with $93.3 \%$ of the upper heads contaminated with honeydew and exuviae; only $13.3 \%$ of the upper heads were severly infested by aphids, only $20 \%$ of them had medium infestation; 66.7 of the heads had light infestation; and none of the heads were healthy. This agrees with results of Bakhetia (1983) and Kelm \& Godomski (1995) who found that yield losses in canola crop caused by B. brassicae can exceed 50\% in Poland, India, China, Australia and New Zealand.

Data in Table (4) show that heads presented on the lower half of the plant stem were more susceptible to infestation with P. xylostella $\mathrm{L}$. than those present on the upper half of the stem. Thus, the larval content / head in the lower half was 3.97 larvae in comparison with 1.5 larvae / head in the upper half. Accordingly, $53.3 \%$ and $46.7 \%$ of heads were partially eaten by worms or had holes in their leaves in the lower half of the stem; compared with 43.3 and $56.7 \%$ in the upper half. No healthy heads remained on the whole plant stem. Contaminated heads with faeces were 96.8 and $73.3 \%$ of the total heads in the lower and upper halves of the stem, respectively (Table 4). This is in accordance with results of Vail et al., (1989) who found that feeding by $P$. xylostella on broccoli plants can physically damage the inflorescence during heading. Also contamination by frass, exuviae, living and dead larvae or pupae had a greater economic importance.

\subsection{The potential injury on Brussels sprouts leaves}

The cabbage aphid injured Brussels sprouts leaves, causing severe, medium and light infestations (Table 4) of 26.7, 33.3 and $30 \%$, respectively, at the end of season. Only $10 \%$ of the leaves were healthy under the natural infestation (78.54 aphids / leaf) during the season.

The diamond back moth larvae injured Brussels sprouts leaves causing partial eating to $50 \%$ of leaves, holes to $40 \%$ of leaves; only $10 \%$ of the leaves remained healthy under the seasonal counts of 0.15 larvae / leaf. This result agrees with the result of Vail et al. (1989), who reported that foliar feeding by $P$. xylostella on broccoli plants impacts indirectly on yield. 
Table (3): Simple correlation (r) and regression (b) between average of the population densities of different insects and two climatic factors during the investigation periods.

\begin{tabular}{|l|c|c|c|c|c|}
\hline \multicolumn{2}{|c|}{ Source of variance } & Host plant & \multicolumn{2}{|c|}{ Temp. $\left({ }^{\circ}\right.$ C ) } & \multicolumn{2}{|c|}{ R.H. $(\%)$} \\
\cline { 3 - 6 } & & r & \multicolumn{2}{|c|}{ b } \\
\hline Population density of B. brassicae during 2005/2006 & Brussels sprouts & $-0.063 \mathrm{~ns}$ & -1.002 & $-0.301 \mathrm{~ns}$ & -5.92 \\
\hline Population density of B. brassicae during 2006/2007 & Brussels sprouts & $0.413 \mathrm{~ns}$ & -35.04 & $-0.37 \mathrm{~ns}$ & -16.42 \\
\hline Population density of B. tabaci during 2005/2006 & Brussels Sprouts & $-0.55 \mathrm{~ns}$ & -6.01 & $0.56 \mathrm{~ns}$ & 7.53 \\
\hline Population density of B. tabaci during 2006/2007 & Brussels Sprouts & $0.17 \mathrm{~ns}$ & 0.204 & $0.14 \mathrm{~ns}$ & 0.08 \\
\hline Population density of T. tabaci during 2006 & Onion & $0.04 \mathrm{~ns}$ & 0.24 & $-0.30 \mathrm{~ns}$ & -2.82 \\
\hline Population density of . tabaci during 2007 & Onoin & $0.26 \mathrm{~ns}$ & 1.99 & $-0.69 \mathrm{~ns}$ & -5.99 \\
\hline
\end{tabular}

Temp. $=$ Temperature R.H, = Relative humidity ns = Not significant.

Table (4): Percentage of heads and leaves of Brussels sprouts suffering from different injury the degrees caused by Brevicoryn brassicae and Plutella xylostella L. at El - Noubarreia, Behera Governorate during 2006/2007 season.

\begin{tabular}{|c|c|c|c|c|c|c|c|c|c|c|c|c|}
\hline \multirow[b]{3}{*}{$\begin{array}{c}\text { Plant } \\
\text { part }\end{array}$} & \multirow[b]{3}{*}{$\begin{array}{l}\text { Position } \\
\text { on stem }\end{array}$} & \multicolumn{6}{|c|}{ Cabbage Aphid } & \multicolumn{5}{|c|}{ Diamondback moth } \\
\hline & & \multirow[b]{2}{*}{$\begin{array}{l}\text { Aphid } \\
\text { counts }\end{array}$} & \multirow{2}{*}{$\begin{array}{c}\text { Parts } \\
\text { with } \\
\text { honeydew } \\
\& \\
\text { exuviae }\end{array}$} & \multicolumn{4}{|c|}{ Injury Degrees } & \multirow[b]{2}{*}{$\begin{array}{c}\text { Larval } \\
\text { content }\end{array}$} & \multirow{2}{*}{$\begin{array}{c}\text { Parts } \\
\text { with } \\
\text { faeces } \\
\& \\
\text { exuviae }\end{array}$} & \multicolumn{3}{|c|}{ Injury degrees } \\
\hline & & & & Severe & Medium & Light & Healthy & & & $\begin{array}{c}\text { Partially } \\
\text { eaten }\end{array}$ & $\begin{array}{l}\text { With } \\
\text { holes }\end{array}$ & Healthy \\
\hline \multirow{2}{*}{ Heads } & Lower & 36.1 & $93.3 \%$ & $60.0 \%$ & $40.0 \%$ & $0.0 \%$ & $0.0 \%$ & 3.97 & $96.8 \%$ & $53.3 \%$ & $46.7 \%$ & $0.0 \%$ \\
\hline & Upper & 9.9 & $93.3 \%$ & $13.3 \%$ & $20.0 \%$ & $66.7 \%$ & $0.0 \%$ & 1.5 & $73.3 \%$ & $43.3 \%$ & $56.7 \%$ & $0.0 \%$ \\
\hline \multicolumn{2}{|c|}{ Leaves } & 78.54 & $90.0 \%$ & $26.7 \%$ & $33.3 \%$ & $30.0 \%$ & $10.0 \%$ & 0.15 & $0.0 \%$ & $50.0 \%$ & $40.0 \%$ & $10.0 \%$ \\
\hline
\end{tabular}




\section{REFERENCES}

Badens-Perez F.R. and Shelton A. M. (2006). Pest management and other agricultural practices among farmers growing cruciferous vegetables in the central and western highlands of Kenya and the western Himalayas of India. International Journal of Pest Management, 52 (4): 303-315.

Bakhetia D.R.C. (1983). Losses in rapseed / mustard due to Lipaphis erysimi in India: a literature review. In Proceedings of the $6^{\text {th }}$ International Rapseed Conference, Paris, May 1983, p. $15-22$.

Bayhan S.O., Ulusoy M.R. and Bayhan E. (2007). Is the parasitization rate of Diaeretiella rapae influenced when Brevicoryne brassicae fed on Brassica plants. Phytoparasitica 35 (2): 146 - 149.

Bodenheimer F.S. (1951). Citrus Entomology in the Middle East W. Junk, Holland, 663 pp.

Douchovskiene L. (2006). The abundance and population dynamics of onion thrips (Thrips tabaci Lind). in leek under field conditions. Agronomy Res., 4 (Special issue): 163 - 166.

El-Gindy M.A.A. (1997). Studies on Certain Pests Infesting Some Vegetable Crops in Dakahlia Governorate, Egypt. M.Sc. Thesis, Fac. of Agric., Zagazig Univ. (Unpublished data).

Farag N.A. (1995). Studies on the Biological Control of Whitefiles and Aphids on Some Vegetable Crops. Ph. D. Thesis, Institute of Environmental Studies \& Res., Ain Shams Univ. (Unpublished data).

Farzadfar S., Ahoonmanesh A., Mosahebi G. H., Pourrahim R. S. and Golnaraghi A.R. (2007). Occurrence and distribution of cauliflower mosaic virus on cruciferous plants in Iran. Plant Pathology J. (Faisalabad), 6 (1): 22-29.

Gomez K.A. and Gomez A.A. (1984). Statistical Procedures for Agricultural Research $2^{\text {nd }}$ ed. John Wiley and Sons, New York. 680 pp.

Hegab A.M. and Helaly M.M. (1989). Occurrence and seasonal abundance of the whitefly, Bemisia tabaci (Genn.) infesting certain cucurbitaceous and cruciferous vegetable plants in newly reclaimed sandy areas at Salhia district, Egypt. Zagazig J. Agric. Res., 16 (1): 130-136.

Hirano K., Budiyanto E. and Winarni S. (1993). Biological characterstics and forecasting outbreaks of the whitefly, Bemisia tabaci, a vector of virus disease in soybean fields.
Technical Bulletin 135: 1-14. Food \& Fertilizer Technology Center, Republic of China.

Hirano K., Budiyanto E., Swastika N. and Fujii K. (1995). Population dynamics of the whitefly, Bemisia tabaci (Genn.) (Homoptera: Aleyrodidae), in Java, Indonesia, with special reference to spatio - temporal changes in the quantity of food resources. Ecological Res., 10: $75-85$.

Kalafchi M., Mobli M., Ebadi R. and Rezaei A.M. (2006) A study of population fluctuations of onoin thrips (Thrips tabaci Lind.) and its effect on bulbing and yield of selected onion cultivars in Asfahan. Iranian J. of Agric. Sci., 36 (6): $1465-1477$.

Kelm M. and Godomski H. (1995). Cabbage aphid, Brevicoryne brassicae (L.), as a pest of oilseed rape crops. In proceeding of the $9^{\text {th }}$ International Rapeseed Congress, Cambridge, UK. 4-7 July 1995, 575-576.

Martin N.A., Workman P.J. and Hedderley D. (2006). Monitoring onion crops for onion thrips, Thrips tabaci. New Zealand Plant Protection, 59: $69-74$.

Ohnesorge, B. and Rapp, G. (1986). Monitoring Bemisia tabaci: A review. Agriculture Ecosystems and Environment, 17: 21-27.

Perry J.N., Parker W.E., Alderson L., Korie S., Blood-Smyth J.A., Mckinlay R. and Ellis S.A. (1998). Simulation of counts of aphids over two hectars of Brussels sprouts plants. Computers and Electronics in Agric. 21: 33 -51 .

Salem H.A. (2002). Population density of insects infesting cabbage seedlings and injury by chewing insects under field conditions of Giza region. Bull. Fac. Agric., Cairo Univ., 53 (2): $327-340$.

Salem H.A. (2003). Stages occurrence, natality rate and dispersal ability of Brevicoryne brassicae (Linne) on cabbage plants at Giza Governorate. Bull. Fac. Agric., Cairo Univ., 54 (2): 293-306.

Salem H.A., El- Komy S.O.O. and Abd El- Salam A.M.E. (2004). Dynamic fluctuations of two thrips species populations infesting some winter host plants. J. Adv. Agric. Res., Fac. Agric, Saba Basha, 9 (2): 401 - 414.

Vail K.M., Kok L. T. and Lentner M. (1989). Broccoli yield response to selected levels of cabbage looper (Lepidoptera: Noctuidae) larvae in southwestern Virginia. J. Econ. Entomol., 82: 1437 - 1443. 
التواجد والكثافة العددية والضرر النهائي لبعض الحشرات التي تصيب كرنب بروكسل و البصل في المناطق الصحراوية بالنوبارية، محافظة البحيرة.

$$
\begin{aligned}
& \text { حمدي عبد التبي سالم- شادية السيد عبد العزيز. } \\
& \text { قسم آفات ووقاية النبات ـ المركز القومي للبحوث ـ الدقي ـ الجيزة- مصر. }
\end{aligned}
$$

\section{ملـخص}

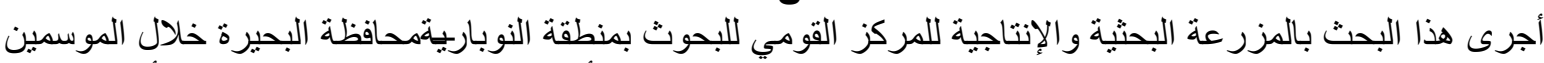

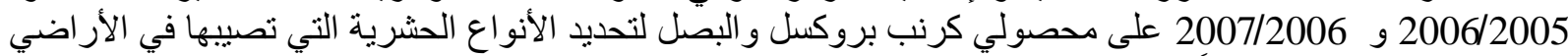

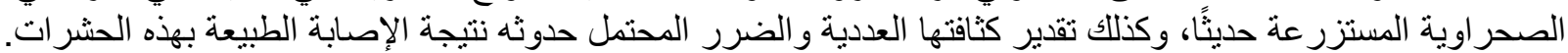

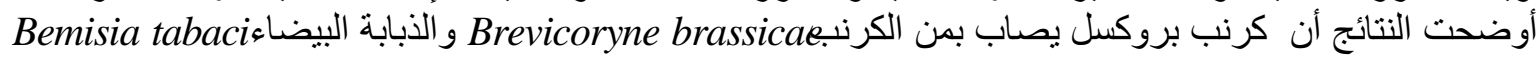

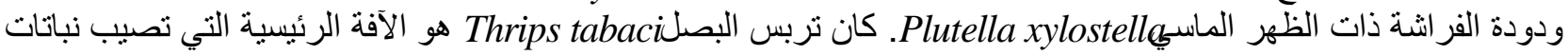

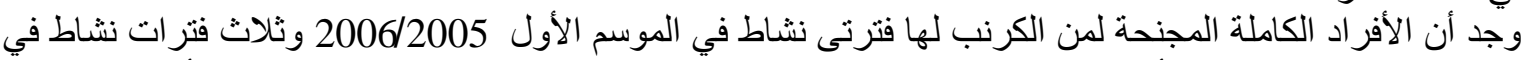
البصل في منطقة الدر اسة.

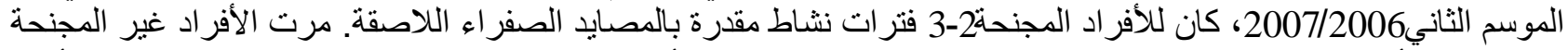

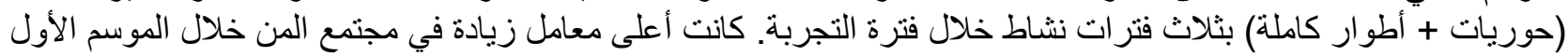

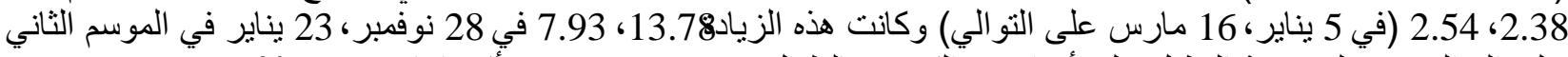

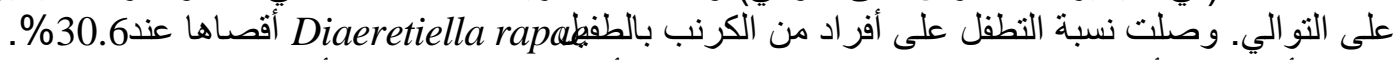

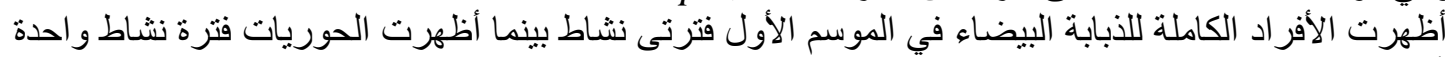

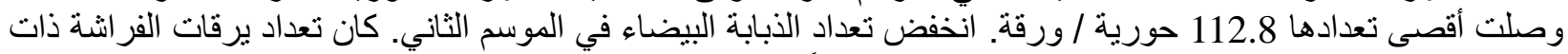

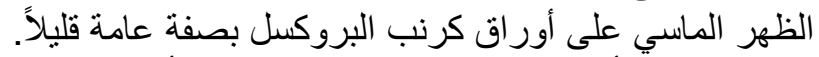

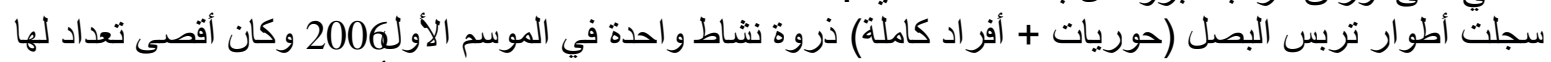

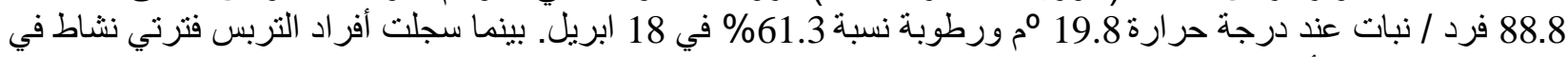

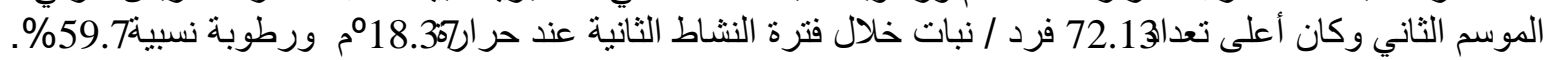

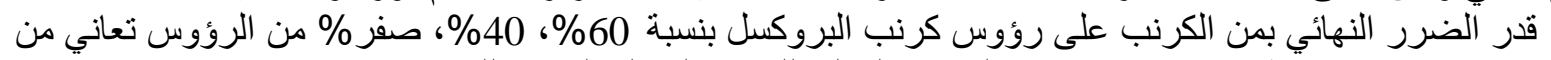

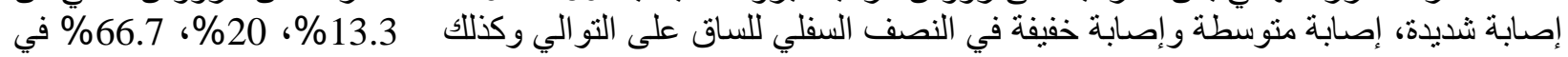

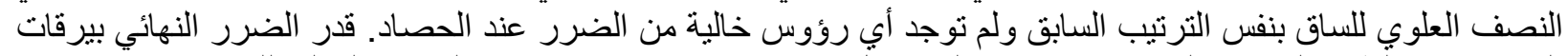

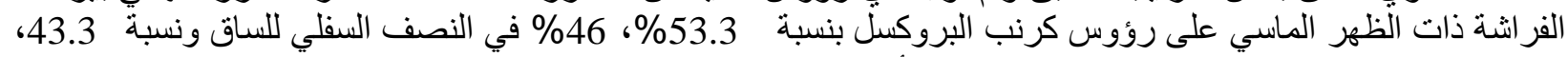

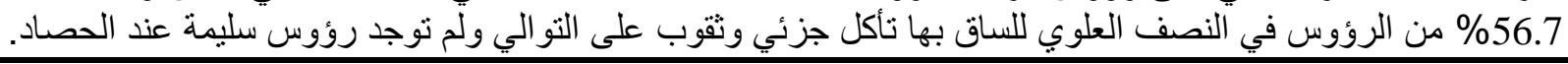

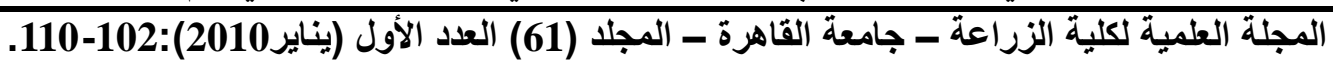

